Review Article

\title{
Plant growth-promoting rhizobacteria (PGPR): Their potential as antagonists and biocontrol agents
}

\author{
Anelise Beneduzi, Adriana Ambrosini and Luciane M.P. Passaglia \\ Universidade Federal do Rio Grande do Sul, Instituto de Biociências, Departamento de Genética, \\ Porto Alegre, RS, Brazil.
}

\begin{abstract}
Bacteria that colonize plant roots and promote plant growth are referred to as plant growth-promoting rhizobacteria (PGPR). PGPR are highly diverse and in this review we focus on rhizobacteria as biocontrol agents. Their effects can occur via local antagonism to soil-borne pathogens or by induction of systemic resistance against pathogens throughout the entire plant. Several substances produced by antagonistic rhizobacteria have been related to pathogen control and indirect promotion of growth in many plants, such as siderophores and antibiotics. Induced systemic resistance (ISR) in plants resembles pathogen-induced systemic acquired resistance (SAR) under conditions where the inducing bacteria and the challenging pathogen remain spatially separated. Both types of induced resistance render uninfected plant parts more resistant to pathogens in several plant species. Rhizobacteria induce resistance through the salicylic acid-dependent SAR pathway, or require jasmonic acid and ethylene perception from the plant for ISR. Rhizobacteria belonging to the genera Pseudomonas and Bacillus are well known for their antagonistic effects and their ability to trigger ISR. Resistance-inducing and antagonistic rhizobacteria might be useful in formulating new inoculants with combinations of different mechanisms of action, leading to a more efficient use for biocontrol strategies to improve cropping systems.
\end{abstract}

Keywords: antagonism, siderophore, antibiotic, SAR, ISR.

\section{Plant-Associated Bacteria - A General Introduction}

The rhizosphere is the narrow zone of soil specifically influenced by the root system (Dobbelaere et al., 2003). This zone is rich in nutrients when compared with the bulk soil due to the accumulation of a variety of plant exudates, such as amino acids and sugars, providing a rich source of energy and nutrients for bacteria (Gray and Smith, 2005). This situation is reflected by the number of bacteria that are found around the roots of plants, generally 10 to 100 times higher than that in the bulk soil (Weller and Thomashow, 1994). The rhizosphere is populated by a diverse range of microorganisms and the bacteria colonizing this habitat are called rhizobacteria (Schroth and Hancock, 1982).

Plant-associated bacteria can be classified into beneficial, deleterious and neutral groups on the basis of their effects on plant growth (Dobbelaere et al., 2003). Beneficial free-living soil bacteria are usually referred to as plant growth-promoting rhizobacteria (PGPR, Kloepper et al.,

Send correspondence Luciane M.P. Passaglia. Departamento de Genética, Instituto de Biociências, Universidade Federal do Rio Grande do Sul, Av. Bento Gonçalves 9500, Caixa Postal 15.053, 91501-970 Porto Alegre, RS, Brazil. E-mail: Ipassaglia@ terra.com.br.
1989). Independent of the mechanisms of vegetal growth promotion, PGPRs colonize the rhizosphere, the rhizoplane (root surface), or the root itself (within radicular tissues) (Gray and Smith, 2005). It is well established that only 1 to $2 \%$ of bacteria promote plant growth in the rhizosphere (Antoun and Kloepper, 2001). Bacteria of diverse genera have been identified as PGPR, of which $B a-$ cillus and Pseudomonas spp. are predominant (Podile and Kishore, 2006).

PGPR affect plant growth in two different ways, indirectly or directly. The direct promotion of plant growth by PGPR entails either providing the plant with a compound that is synthesized by the bacterium, for example phytohormones, or facilitating the uptake of certain nutrients from the environment (Glick, 1995). The indirect promotion of plant growth occurs when PGPR lessen or prevent the deleterious effects of one or more phytopathogenic organisms. This can happen by producing antagonistic substances or by inducing resistance to pathogens (Glick, 1995). A particular PGPR may affect plant growth and development by using any one, or more, of these mechanisms. PGPR, as biocontrol agents, can act through various mechanisms, regardless of their role in direct growth promotion, such as by known production of auxin phytohormone (Patten and Glick, 2002), decrease of plant ethylene levels 
(Glick et al., 2007) or nitrogen fixing associated with roots (Döbereiner, 1992).

PGPR and their interactions with plants are exploited commercially (Podile and Kishore, 2006) and hold great promise for sustainable agriculture. Applications of these associations have been investigated in maize, wheat, oat, barley, peas, canola, soy, potatoes, tomatoes, lentils, radicchio and cucumber (Gray and Smith, 2005).

In this review, we will consider the mechanisms of action of biocontrol agents and describe some successful examples of these rhizobacteria controlling plant diseases.

\section{Microbial Antagonism}

According to Beattie (2006), bacteria that reduce the incidence or severity of plant diseases are often referred to as biocontrol agents whereas those that exhibit antagonistic activity toward a pathogen are defined as antagonists. The following rhizospheric environment and bacterial antagonistic activities can be highlighted: (1) synthesis of hydrolytic enzymes, such as chitinases, glucanases, proteases, and lipases, that can lyse pathogenic fungal cells (Neeraja et al. 2010; Maksimov et al. 2011), (2) competition for nutrients and suitable colonization of niches at the root surface (Stephens et al., 1993; Kamilova et al. 2005; Validov S, 2007, PhD thesis, Leiden University, The Netherlands), (3) regulation of plant ethylene levels through the ACC-deaminase enzyme, which can act to modulate the level of ethylene in a plant in response to stress imposed by the infection (Glick and Bashan, 1997; Van Loon, 2007), and (4) production of siderophores and antibiotics.

\section{Siderophores, bacteriocins, and antibiotics production as antagonistic activities}

The ability of rhizobacteria to produce siderophores and metabolites contributing to antibiosis has been the focus of many studies dedicated to investigating PGPR (Maksimov et al., 2011). The uptake of ferric ion via siderophore is largely used by pathogenic and non-pathogenic microorganisms from the soil, human body and marine environments. The importance of siderophore is closely related to iron, which is an essential element for different biological processes (Crosa and Walsh, 2002). On the other hand, bacteria can produce a wide variety of compounds with antimicrobial activity used as defense systems. These include broad-spectrum antibiotics, lactic acid produced by lactobacilli, lytic agents such as lysozymes, numerous types of exotoxins and bacteriocins, which also have a bactericidal mode of action (Riley and Wertz, 2002). Siderophores, bacteriocins and antibiotics are three of the most effective and well known mechanisms that an antagonist can employ to minimize or prevent phytopathogenic proliferation.

\section{Siderophores}

To satisfy nutritional requirements of iron, microorganisms have evolved highly specific pathways that employ low molecular weight iron chelators termed siderophores. Siderophores are secreted to solubilize iron from their surrounding environments, forming a complex ferric-siderophore that can move by diffusion and be returned to the cell surface (Andrews et al., 2003). The active transport system through the membrane begins with the recognition of the ferric-siderophore by specific membrane receptors of Gram-negative and Gram-positive bacteria (Boukhalfa and Crumbliss, 2002). Siderophores can chelate ferric ion with high affinity, allowing its solubilization and extraction from most mineral or organic complexes (Wandersman and Delepelaire, 2004). In aerobic conditions at physiological $\mathrm{pH}$, the reduced ferrous $\left(\mathrm{Fe}^{2+}\right)$ form is unstable and is readily oxidized to the oxidized ferric $\left(\mathrm{Fe}^{3+}\right)$ form, which normally occurs as a poorly soluble iron hydroxide basically unavailable to biological systems (Krewulak and Vogel, 2008; Osorio et al., 2008).

Siderophores can be defined as small peptidic molecules containing side chains and functional groups that can provide a high-affinity set of ligands to coordinate ferric ions (Crosa and Walsh, 2002). Based on their iron-coordinating functional groups, structural features and types of ligands, bacterial siderophores have been classified into four main classes (carboxylate, hydroxamates, phenol catecholates and pyoverdines) (Crowley, 2006). Hundreds of siderophores have been identified and reported for cultivable microorganisms, some of which are widely recognized and used by different microorganisms, while others are species-specific (Crowley, 2006; Sandy and Butler, 2009).

In soil, siderophore production activity plays a central role in determining the ability of different microorganisms to improve plant development. Microbial siderophores enhance iron uptake by plants that are able to recognize the bacterial ferric-siderophore complex (Masalha et al. 2000; Katiyar and Goel, 2004; Dimkpa et al., 2009) and are also important in the iron uptake by plants in the presence of other metals such as nickel and cadmium (Burd et al., 1998; Dimkpa et al., 2008). However, it is still unclear if bacterial siderophore complexes can significantly contribute to the iron requirements of the plant.

Siderophore production confers competitive advantages to PGPR that can colonize roots and exclude other microorganisms from this ecological niche (Haas and Défago, 2005). Under highly competitive conditions, the ability to acquire iron via siderophores may determine the outcome of competition for different carbon sources that are available as a result of root exudation or rhizodeposition (Crowley, 2006). Among most of the bacterial siderophores studied, those produced by pseudomonads are known for their high affinity to the ferric ion. The potent siderophore, pyoverdin, for example, can inhibit the growth of bacteria and fungi that present less potent siderophores in 
iron-depleted media in vitro (Kloepper et al. 1980a). A pseudobactin siderophore produced by $P$. putida $\mathrm{B} 10$ strain was also able to suppress Fusarium oxysporum in soil deficient in iron; this suppression was lost when the soil was replenished with iron, a condition that represses the production of iron chelators by microorganisms (Kloepper et al., 1980b). Recent studies have demonstrated the suppression of soil-borne fungal pathogens through the release of ironchelating siderophores by fluorescent pseudomonads, rendering it unavailable to other organisms (Loper, 1988; Paulitz and Loper, 1991; Dwivedi and Johri, 2003).

\section{Antibiotics}

Besides siderophore production, the biocontrol abilities of pseudomonad strains essentially depend on aggressive root colonization, induction of systemic resistance in the plant, and production of antifungal antibiotics (Haas and Keel, 2003). The production of one or more antibiotics is the mechanism most commonly associated with the ability of plant growth-promoting bacteria to act as antagonistic agents against phytopathogens (Glick et al., 2007). The basis of antibiosis, activity of biocontrol based on secretion of molecules that kill or reduce the growth of the target pathogen, has become better understood over the past two decades (Dowling and O'Gara, 1994; Whipps, 2001; Lugtenberg and Kamilova, 2009). Antibiotics encompass a heterogeneous group of organic, low-molecular-weight compounds that are deleterious to the growth or metabolic activities of other microorganisms (Duffy, 2003).

According to Haas and Défago (2005), six classes of antibiotic compounds (for which their modes of action are partly understood) are better related to the biocontrol of root diseases: phenazines, phloroglucinols, pyoluteorin, pyrrolnitrin, cyclic lipopeptides (all of which are diffusible) and hydrogen cyanide (HCN; which is volatile). More recently, lipopeptide biosurfactants produced by Pseudomonas and Bacillus species have been implied in biocontrol due to their potential positive effect on competitive interactions with organisms including bacteria, fungi, oomycetes, protozoa, nematodes and plants (de Bruijn et al., 2007; Raaijmakers et al., 2010).

Numerous types of antibiotics have been isolated from fungal and bacterial strains and this diversity includes mechanisms of action that inhibit synthesis of pathogen cell walls, influence membrane structures of cells and inhibit the formation of initiation complexes on the small subunit of the ribosome (Maksimov et al., 2011). Pyrrolnitrin, the antibiotic produced by the $P$. fluorescens BL915 strain, is able to prevent the damage of Rhizoctonia solani during damping-off of cotton plants (Hill et al., 1994). The 2,4-diacetylphloroglucinol (DAPG) produced by pseudomonads, an effective and extensively studied antibiotic, causes membrane damage to Pythium spp. and is particularly inhibitory to zoospores of this oomycete (de Souza et al., 2003). Phenazine, also produced by pseudomonads, possesses re- dox activity and can suppress pathogens of plants such as $F$. oxysporum and Gaeumannomyces graminis (Chin-AWoeng et al., 2003). The P. chlororaphis PCL1391 strain, isolated from roots of tomato plants, synthesizes phenazine-1-carboxamide, which is able to release soluble iron from insoluble ferric oxides at neutral $\mathrm{pH}$, raising the possibility that phenazines might contribute to iron mobilization in soils (Hernandez et al., 2004; Haas and Défago, 2005).

Antibiotics, such as polymyxin, circulin and colistin, produced by the majority of Bacillus ssp. are active against Gram-positive and Gram-negative bacteria, as well as many pathogenic fungi (Maksimov et al., 2011). The B. cereus UW85 strain, which suppresses oomycete pathogens and produces the antibiotics zwittermicin A (aminopolyol) and kanosamine (aminoglycoside), contributes to the biocontrol of alfalfa damping off (Silo-Suh et al., 1994; He et al., 1994). Regarding bacteria as biocontrol agents to act as a biological solution, some researchers have highlighted the use of sporulating Gram-positive species such as Bacillus and Paenibacillus spp., which can confer higher population stability during formulation and storage of inoculant products (Emmert and Handelsman, 1999; Kokalis-Burelle et al., 2005).

\section{Bacteriocins}

Other molecules used in microbial defense systems are bacteriocins. According to a review by Riley and Wertz (2002), bacteriocins differ from traditional antibiotics in one critical way: they commonly have a relatively narrow killing spectrum and are only toxic to bacteria closely related to the producing strain. Almost all bacteria may make at least one bacteriocin, and many bacteriocins isolated from Gram-negative bacteria appear to have been created by recombination between existing bacteriocins (Riley, 1993). The colicins, proteins produced by some strains of Escherichia coli that are lethal for related strains, are the most representative bacteriocins produced by Gram-negative bacteria. Like colicin, a name derived from E. coli, other bacteriocins have been thus defined and named, such as pyocins from $P$. pyogenes strains, cloacins from Enterobacter cloacae, marcescins from Serratia marcescens and megacins from B. megaterium (Cascales et al., 2007). Interestingly, bacteriocins from Bacillus spp. are increasingly becoming more important due to their sometimes broader spectra of inhibition (as compared with most lactic bacterial bacteriocins), which may include Gram-negative bacteria, yeasts or fungi, in addition to Gram-positive species, some of which are known to be pathogenic to humans and/or animals (Abriouel et al., 2011).

\section{Biocontrol Agents - Induced Resistance (ISR and SAR)}

Non-pathogenic rhizobacteria have been shown to suppress disease by inducing a resistance mechanism in the 
plant called "Induced Systemic Resistance" (ISR) (Van Loon et al., 1998). Induced resistance is the state of an enhanced defensive ability developed by plants when appropriately stimulated (Van Loon et al., 1998). ISR was formerly described by Van Peer et al. (1991) in carnation plants that was systemically protected by the $P$. fluorescens strain WCS417r against $F$. oxysporum $\mathrm{f}$. sp. dianthi and by Wei et al. (1991) in cucumber plants, where rhizobacterial strains protected the leaves against anthracnose caused by Colletotrichum orbiculare. The inducing rhizobacteria and the pathogens were inoculated and remained confined and spatially separated on the same plant so that microbial antagonism was excluded and the protective effect was plant-mediated.

Rhizobacteria-mediated ISR resembles pathogen-induced systemic acquired resistance (SAR) in that both types of induced resistance render uninfected plant parts more resistant to plant pathogens (Van Wees et al., 1997; Van Loon et al., 1998), including fungal, bacterial and viral pathogens, as well as nematodes and insects (Zehnder et al., 1997; Van Loon et al., 1998; Bent, 2006; Pozo and AzconAguilar, 2007). The same strain induces resistance against several pathogens in the same plant (Somers et al. 2004). Specifically, Pseudomonas and Bacillus spp. are the rhizobacteria most studied that trigger ISR (Kloepper et al., 2004; Van Wees et al., 2008). Vleesschauwer and Höfte (2009) proposed the terminology ISR to depict induced systemic resistance promoted by non-pathogenic rhizobacteria or PGPR, irrespective of the signaling pathway involved in this process, while the term SAR is used to describe salicylic acid-dependent induced resistance triggered by a localized infection.

ISR and SAR act through different signaling pathways. Induction of SAR is through salicylic acid (SA) and ISR requires jasmonic acid (JA) and ethylene (ET) signaling pathways (Van Loon et al., 1998). These accumulating signaling molecules coordinate the defense responses and when applied exogenously, are sufficient to induce resistance (Ryals et al., 1996). The protection mediated by ISR is significantly less than that obtained by SAR (Van Loon, 2000) and a degree of dependence on plant genotype is observed in the generation of ISR (Bloemberg and Lugtenberg, 2001). However, ISR and SAR together provide a better protection than each of them alone, indicating that they can act additively in inducing resistance to pathogens (Van Wees et al., 2000).

Salicylic acid accumulation occurs both locally and, at lower levels, systemically, in line with the development of SAR. Application of exogenous SA also induces SAR in many plant species (Van Loon et al., 1998). Development of tissue necrosis used to be considered a common and necessary feature for SAR activation (Vleesschauwer and Höfte, 2009), but in many cases, SAR can also be triggered without tissue necrosis as demonstrated in Arabidopsis thaliana (Mishina and Zeier, 2007). In SAR, the first infec- tion predisposes the plant to resist further attacks. SA activates specific sets of defense-related genes called pathogenesis-related proteins (PRs). Generally, ISR is not accompanied by the activation of PR genes. The enhanced defensive capacity characteristic of SAR is always associated with the accumulation of PRs (Van Loon, 2007). Treatment of tobacco roots with $P$. fluorescens CHA0 triggers accumulation of SA-inducible PR proteins in the leaves (Maurhofer et al., 1994). These PRs serve as hallmarks of SAR in several plant species and are thought to contribute to the state of resistance attained (Vleesschauwer and Höfte, 2009). Some of these PRs are 1,3-glucanases and chitinases capable of hydrolyzing fungal cell walls, while other PRs are poorly characterized. SARassociated PRs suggest an important contribution of these proteins to the increased defensive capacity of induced tissues (Van Loon et al., 1998).

The PR-1 gene or protein expression appears to be inducible by SA and it is usually taken as a molecular marker to indicate that SAR has been induced (Van Loon and Bakker, 2006). Arabidopsis plants inoculated with the pathogen P. syringae pv. tomato or sprayed with SA developed SAR and accumulated PR-1, -2 and -5 mRNAs (Pieterse et al., 1996) and inoculated with P. fluorescens WCS417r or P. putida WCS358 developed ISR, but PRgene expression or accumulation of PRs was not detected (Van Wees et al., 1997). ISR can be triggered in plants that are unable to accumulate SA (NahG mutant plants). Based on this, one can conclude that PRs are induced concomitantly with SAR, whereas SA and the activation of PR genes is not part of the pathway leading to ISR in Arabidopsis (Pieterse et al., 1996).

Transduction of the SA signal requires the regulatory (activator) protein NPR1 (or NIM1) that functions in the terminal part of the signaling pathway of SAR (Van Loon et al., 1998). In non-induced plants, NPR1 is present as a multimer and during SAR induction, SA triggers the conversion of NPR1 into a monomeric form (Verhagen et al. 2006). These monomers are translocated to the nucleus (Kinkema et al. 2000), where they interact with members of the TGA/OBF subclass of basic-leucine-zipper (bZIP) transcription factors that are involved in SA-dependent activation of PR genes (Fan and Dong, 2002; Zhang et al., 2003). A direct interaction between NPR1 and a specific TGA transcription factor is required for the binding of the complex to elements within the promoter of the PR genes (Després et al., 2000; Fan and Dong, 2002). Overexpression of the NPR1 gene leads to enhanced resistance to pathogen attack (Cao et al., 1998; Friedrich et al., 2001).

The Arabidopsis mutant nprl does not express PR genes and does not exhibit SAR. Since rhizobacteriamediated ISR is independent of SA and not associated with PRs, it is expected that ISR would still be expressed in this mutant. However, the npr 1 mutant of Arabidopsis does not display $P$. fluorescens WCS417r-mediated ISR. This 
implies that NPR 1 regulates defense responses mediated by different signaling pathways that function beyond the expression of PR genes, indicating that SAR and ISR converge at the last part of the signaling pathway (Van Loon et al., 1998). Reports of Pieterse et al. (1996, 1998, 2000) with the reference rhizobacterial strain $P$. fluorescens WCS417r demonstrated that, at least in Arabidopsis, WCS417r-mediated ISR functioned independently of SA, depended on NPR1, but required components of the JA and ethylene (ET) response pathways.

Infected plants increased their levels of JA and ET as a sign of active defense (De Laat and Van Loon, 1982; Gundlach et al., 1992; Mauch et al., 1994). These signaling molecules coordinate the activation of a large set of defense responses and when applied exogenously, can induce resistance themselves (Pieterse et al., 1998). The dependency of ISR on JA and ethylene is based on enhanced sensitivity to these hormones rather than on an increase in their production (Pieterse et al., 2000, 2001). The Arabidopsis JA response mutant jarl and the ET response mutant etrl were tested in the development of ISR. Both mutants were unable to develop ISR against $P$. syringae pv. tomato upon colonization of the roots by WCS417r bacteria (Pieterse $e t$ al., 1998), illustrating the dependency of ISR signaling on these phytohormones. The signal-transduction pathways leading to pathogen-induced SAR and rhizobacteriamediated ISR in Arabidopsis thaliana are summarized in Figure 1.

Methyl jasmonate (MeJA) and the ethylene precursor 1-aminocyclopropane-1-carboxylate (ACC) also promote resistance against $P$. syringae pv. tomato DC3000 in SAnon-accumulating NahG plants. Besides that, MeJAinduced protection is blocked in jarl-1, etr $1-1$ and nprl-1 plants, whereas ACC-induced protection is affected in etr 1-1 and nprl-1 plants, but not in jarl-1 plants. Therefore, WCS417r-mediated ISR follows a signaling pathway

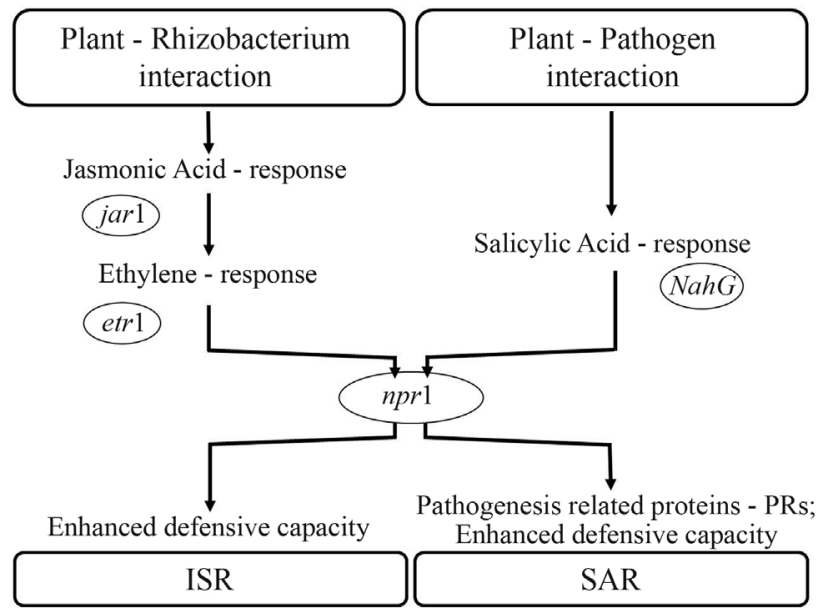

Figure 1 - Signal transduction pathways leading to pathogen-induced systemic acquired resistance (SAR) and rhizobacteria-mediated induced systemic resistance (ISR) in Arabidopsis thaliana. Modified from: Van Loon et al., 1998. in which components from the JA and ethylene response pathways are successively engaged to trigger a defense reaction that, like SAR, is regulated by NPR1 (Pieterse et al., 1998).

One or more bacterial determinant must be recognized by specific plant receptors so that resistance is induced. A variety of resistance-inducing molecules have been described: lipopolysaccharides and siderophores, including SA (Van Loon et al., 1998), flagella, biosurfactants, N-acyl-homoserine lactones (AHL), N-alkylated benzylamines, antibiotics and exopolysaccharides (EPS) (Vleesschauwer and Höfte, 2009).

The ability to develop ISR in response to certain rhizobacteria has been demonstrated in several species of plants (Van Loon et al., 1998) and appears to depend on the specificity of the interaction between rhizobacteria and plants (Van Loon, 2007). Failure to elicit ISR in certain hosts may be due to the absence of production of inducing components in the rhizosphere or an inability of the particular plant species to perceive such compounds (Van Loon, 2007). The evidence support that it is necessary specific recognition between the plant and the rhizobacteria for induction of resistance. For instance, Pseudomonas putida WCS358r and P. fluorescens WCS374r act in different ways depending on the plant species: in Arabidopsis, WCS358r elicits ISR, but not in radish and carnation plants (Van Peer et al., 1991; Van Peer and Schippers, 1992; Leeman et al., 1995; Van Wees et al., 1997). In contrast, radish plants are responsive to WCS374r, while Arabidopsis is not (Leeman et al., 1995; Van Wees et al., 1997).

\section{Conclusion}

The ability of bacterial siderophores and antibiotics to suppress phytopathogens could be of significant agronomic importance. Both mechanisms have essential functions in microbial antagonism but also are able to elicit induced resistance. Resistance-inducing and antagonistic rhizobacteria might be useful in formulating new inoculants, offering an attractive alternative of environmentally friendly biological control of plant disease and improving the cropping systems into which it can be most profitably applied. These new PGPR will require a systematic strategy designed to fully utilize all these beneficial factors, applying combinations of different mechanisms of action allowing crop yields to be maintained or even increased while chemical treatments are reduced.

\section{Acknowledgments}

This work was financed by a grant and fellowships from the Conselho Nacional de Desenvolvimento Científico e Tecnológico (CNPq/Brazil) and the INCT da Fixação Biológica do Nitrogênio (Brazil). 


\section{References}

Abriouel H, Franz CM, Ben Omar N and Gálvez A (2011) Diversity and applications of Bacillus bacteriocins. FEMS Microbiol Rev 35:201-232.

Andrews SC, Robinson AK and Rodríguez-Quiñones F (2003) Bacterial iron homeostasis. FEMS Microbiol Rev 27:215237.

Antoun H and Kloepper JW (2001) Plant growth promoting rhizobacteria. In: Brenner S and Miller JH (eds) Encyclopedia of Genetics. Academic, New York, pp 1477-1480.

Beattie GA (2006) Plant-associated bacteria: Survey, molecular phylogeny, genomics and recent advances. In: Gnanamanickam SS (ed) Plant-Associated Bacteria. Springer, Dordrecht, pp 1-56.

Bent E (2006) Induced systemic resistance mediated by plant growth-promoting rhizobacteria (PGPR) and fungi (PGPF). In: Tuzun S and Bent E (eds) Multigenic and Induced Systemic Resistance in Plants. Springer Science, New York, pp 225-259.

Bloemberg GV and Lugtenberg BJ (2001) Molecular basis of plant growth promotion and biocontrol by rhizobacteria. Curr Opin Plant Biol 4:343-350.

Boukhalfa H and Crumbliss AL (2002) Chemical aspects of siderophore mediated iron transport. BioMetals 15:325-339.

Burd GI, Dixon DG and Glick BR (1998) A plant growthpromoting bacterium that decreases nickel toxicity in seedlings. Appl Environ Microbiol 64:3663-3668.

Cao H, Li X and Dong X (1998) Generation of broad-spectrum disease resistance by overexpression of an essential regulatory gene in systemic acquired resistance. Proc Natl Acad Sci USA 95:6531-6536.

Cascales E, Buchanan SK, Duché D, Kleanthous C, Lloubès R, Postle K, Riley M, Slatin S and Cavard D (2007) Colicin Biology. Microbiol Mol Biol Rev 71:158-229.

Chin-A-Woeng TF, Bloemberg GV and Lugtenberg BJ (2003) Phenazines and their role in biocontrol by Pseudomonas bacteria. New Phytol 157:503-523.

Crosa JH and Walsh CT (2002) Genetics and assembly line enzymology of siderophore biosynthesis in bacteria. Microbiol Mol Biol Rev 66:223-249.

Crowley DE (2006) Microbial siderophores in the plant rhizospheric. In: Barton LL and Abadía J (eds) Iron Nutrition in Plants and Rhizospheric Microorganisms. Springer, Dordrecht, pp 169-198.

de Bruijn I, de Kock MJD, Yang M, de Waard P, van Beek TA and Raaijmakers JM (2007) Genome-based discovery, structure prediction and functional analysis of cyclic lipopeptide antibiotics in Pseudomonas species. Mol Microbiol 63:417-428.

De Laat AMM and Van Loon LC (1982) Regulation of ethylene biosynthesis in virus-infected tobacco leaves: II. Time course of levels of intermediates and in vivo conversion rates. Plant Physiol 69:240-245.

de Souza JT, Arnould C, Deulvot C, Lemanceau P, Gianinazzi-Pearson V and Raaijmakers JM (2003) Effect of 2,4-diacetylphloroglucinol on Pythium: Cellular responses and variation in sensitivity among propagules and species. Phytopathology 93:966-975.

Després C, DeLong C, Glaze S, Liu E and Fobert PR (2000) The Arabidopsis NPR1/NIM1 protein enhances the DNA binding activity of a subgroup of the TGA family of bZIP transcription factors. Plant Cell 12:279-290.
Dimkpa C, Svatos A, Merten D, Büchel G and Kothe E (2008) Hydroxamate siderophores produced by Streptomyces acidiscabies E13 bind nickel and promote growth in cowpea (Vigna unguiculata L.) under nickel stress. Can J Microbiol 54:163-172.

Dimkpa CO, Merten D, Svatos A, Büchel G and Kothe E (2009) Siderophores mediate reduced and increased uptake of cadmium by Streptomyces tendae F4 and sunflower (Helianthus annuus), respectively. J Appl Microbiol 107:1687-1696.

Dobbelaere S, Vanderleyden J and Okon Y (2003) Plant growthpromoting effects of diazotrophs in the rhizosphere. CRC Crit Rev Plant Sci 22:107-149.

Döbereiner J (1992) History and new perspectives of diazotrophs in association with non-leguminous plants. Symbiosis $13: 1-13$.

Dowling DN and O'Gara F (1994) Metabolites of Pseudomonas involved in the biocontrol of plant disease. Trends Biotechnol 12:133-141.

Duffy B (2003) Pathogen self-defense: Mechanisms to counteract microbial antagonism. Annu Rev Phytopathol 41:501-38.

Dwivedi D and Johri BN (2003) Antifungals from fluorescent pseudomonads: Biosynthesis and regulation. Curr Sci 12:1693-1703.

Emmert EAB and Handelsman J (1999) Biocontrol of plant disease: A (Gram-) positive perspective. FEMS Microbiol Lett 171:1-9.

Fan W and Dong X (2002) In vivo interaction between NPR1 and transcription factor TGA2 leads to salicylic acid-mediated gene activation in Arabidopsis. Plant Cell 14:1377-1389.

Friedrich L, Lawton K, Dietrich R, Willits M, Cade R and Ryals J (2001) NIM1 over expression in Arabidopsis potentiates plant disease resistance and results in enhanced effectiveness of fungicides. Mol Plant Microbe Interact 14:11141124.

Glick BR (1995) The enhancement of plant growth by free-living bacteria. Can J Microbiol 41:109-117.

Glick BR and Bashan Y (1997) Genetic manipulation of plant growth-promoting bacteria to enhance biocontrol of phytopathogens. Biotechnol Adv 15:353-378.

Glick BR, Cheng Z, Czarny J and Duan J (2007) Promotion of plant growth by ACC deaminase-producingsoil bacteria. Eur J Plant Pathol 119:329-39.

Gray EJ and Smith DL (2005) Intracellular and extracellular PGPR: Commonalities and distinctions in the plant-bacterium signaling processes. Soil Biol Biochem 37:395-412.

Gundlach H, Mueller MJ, Kutchan TM and Zenk MH (1992) Jasmonic acid is a signal transducer in elicitor-induced plant cell cultures. Proc Natl Acad Sci USA 89:2389-2393.

Haas D and Défago G (2005) Biological control of soil-borne pathogens by fluorescent pseudomonads. Nat Rev Microbiol 3:307-319.

Haas D and Keel C (2003) Regulation of antibiotic production in root-colonizing Pseudomonas spp. and relevance for biological control of plant disease. Annu Rev Phytopathol 41:117153.

He H, Silo-Suh LA, Handelsman J and Clardy J (1994) Zwittermicin A, an antifungal and plant protection agent from Bacillus cereus. Tetrahedron Lett 35:2499-2502.

Hernandez ME, Kappler A and Newman DK (2004) Phenazines and other redox-active antibiotics promote microbial mineral reduction. Appl Environ Microbiol 70:921-928. 
Hill DS, Stein JI, Torkewitz NR, Morse AM, Howell CR, Pachlatko JP, Becker JO and Ligon JM (1994) Cloning of genes involved in the synthesis of pyrrolnitrin from Pseudomnas fluorescens and role of pyrrolnitrin synthesis in biological control of plant disease. Appl Environ Microbiol 60:78-85.

Kamilova F, Validov S, Azarova T, Mulders I and Lugtenberg B (2005) Enrichment for enhanced competitive plant root tip colonizers selects for a new class of biocontrol bacteria. Environ Microbiol 7:1809-1817.

Katiyar V and Goel R (2004) Siderophore-mediated plant growth promotion at low temperature by mutant of fluorescent pseudomonad. Plant Growth Regul 42:239-244.

Kinkema M, Fan W and Dong X (2000) Nuclear localization of NPR1 is required for activation of PR gene expression. Plant Cell 12:2339-2350.

Kloepper JW, Leong J, Teintze M and Schroth MN (1980a) Enhancing plant growth by siderophores produced by plant growth-promoting rhizobacteria. Nature 286:885-886.

Kloepper JW, Leong J, Teintze M and Schroth MN (1980b) Pseudomonas siderophores: A mechanism explaining diseasesuppressive soils. Curr Microbiol 4:317-320.

Kloepper JW, Lifshitz R and Zablotowicz RM (1989) Free-living bacterial inocula for enhancing crop productity. Trends Biotechnol 7:39-43.

Kloepper JW, Ryu C-M and Zhang SA (2004) Induced systemic resistance and promotion of plant growth by Bacillus spp. Phytopathology 94:1259-1266.

Kokalis-Burelle N, Kloepper JW and Reddy MS (2005) Plant growth-promoting rhizobacteria as transplant amendments and their effects on indigenous rhizosphere microorganisms. Appl Soil Ecol 31:91-100.

Krewulak KD and Vogel HJ (2008) Structural biology of bacterial iron uptake. Biochim Biophys Acta 1778:1781-1804.

Leeman M, Van Pelt JA, Den Ouden FM, Heinsbroek M, Bakker PAHM and Schippers B (1995) Induction of systemic resistance by Pseudomonas fluorescens in radish cultivars differing in susceptibility to fusarium wilt, using a novel bioassay. Eur J Plant Pathol 101:655-664.

Loper JE (1988) Role of fluorescent siderophore production in biological control of Pythium ultimum by a Pseudomonas fluorescens strain. Phytopathology 78:166-172.

Lugtenberg B and Kamilova F (2009) Plant-growth-promoting rhizobacteria. Annu Rev Microbiol 63:541-55.

Maksimov IV, Abizgil'dina RR and Pusenkova LI (2011) Plant growth promoting rhizobacteria as alternative to chemical crop protectors from pathogens (Review). Appl Biochem Microbiol 47:333-345.

Masalha J, Kosegarten H, Elmaci Ö and Mengel K (2000) The central role of microbial activity for iron acquisition in maize and sunflower. Biol Fert Soils 30:433-439.

Mauch F, Hadwiger LA and Boller T (1994) Ethylene: Symptom, not signal for the induction of chitinase and-1,3-glucanase in pea pods by pathogens and elicitors. Plant Physiol 76:607611.

Maurhofer M, Hase C, Meuwly P, Métraux JP and Défago G (1994) Induction of systemic resistance of tobacco to tobacco necrosis virus by the root-colonizing Pseudomonas fluorescens strain CHA0: Influence of the gacA gene and of pyover-dine production. Phytopathology 84:139-46.

Mishina TE and Zeier J (2007) Pathogen-associated molecular pattern recognition rather than development of tissue necro- sis contributes to bacterial induction of systemic acquired resistance in Arabidopsis. Plant J 50:500-513.

Neeraja C, Anil K, Purushotham P, Suma K, Sarma P, Moerschbacher BM and Podile AR (2010) Biotechnological approaches to develop bacterial chitinases as a bioshield against fungal diseases of plants. Crit Rev Biotechnol 30:231-241

Osório H, Martinez V, Nieto PA, Holmes DS and Quatrini R (2008) Microbial iron management mechanisms in extremely acidic environments: Comparative genomics evidence for diversity and versatility. BMC Microbiology 8:203.

Patten CL and Glick BR (2002) Role of Pseudomonas putida indoleacetic acid in development of the host plant root system. Appl Environ Microbiol 68:3795-3801.

Paulitz TC and Loper JE (1991) Lack of a role for fluorescent siderophore production in the biological control of Pythium damping-off of cucumber by a strain of Pseudomonas putida. Phytopathology 81:930-935.

Pieterse CMJ, Van Wees SCM, Hoffland E, Van Pelt JA and Van Loon LC (1996) Systemic resistance in Arabidopsis induced by biocontrol bacteria is independent of salicylic acid accumulation and pathogenesis-related gene expression. Plant Cell 8:1225-1237.

Pieterse CMJ, Van Wees SCM, Van Pelt JA, Knoester M, Laan R, Gerrits H, Weisbeek PJ and Van Loon LC (1998) A novel signaling pathway controlling induced systemic resistance in Arabidopsis. Plant Cell 10:1571-1580.

Pieterse CMJ, Van Pelt JA, Ton J, Parchmann S, Mueller MJ, Buchala AJ, Métraux J-P and Van Loon LC (2000) Rhizobacteria-mediated induced systemic resistance (ISR) in Arabidopsis requires sensitivity to jasmonate and ethylene but is not accompanied by an increase in their production. Physiol Mol Plant Pathol 57:123-134.

Pieterse CMJ, Ton J and Van Loon LC (2001) Cross-talk between plant defence signalling pathways: Boost or burden? AgBiotechNet 3:ABN068.

Podile AR and Kishore GK (2006) Plant growth-promoting rhizobacteria. In: Gnanamanickam SS (ed) Plant-Associated Bacteria. Springer, Netherlands, pp 195-230.

Pozo MJ and Azcón-Aguilar C (2007) Unraveling mycorrhiza-induced resistance. Curr Opin Plant Biol 10:393-398.

Raaijmakers JM, de Bruijn I, Nybroe O and Ongena M (2010) Natural functions of lipopeptides from Bacillus and Pseudomonas: More than surfactants and antibiotics. FEMS Microbiol Rev 34:1037-1062.

Riley M (1993) Molecular mechanisms of colicin evolution. Mol Biol Evol 10:1380-95.

Riley MA and Wertz JE (2002) Bacteriocins: Evolution, ecology,and application. Annu Rev Microbiol 56:117-137.

Ryals JA, Neuenschwander UH, Willits MG, Molina A, Steiner H-Y and Hunt MD (1996) Systemic acquired resistance. Plant Cell 8:1808-19.

Sandy M and Butler A (2009) Microbial iron acquisition: Marine and terrestrial siderophores. Chem Rev 109:4580-4595.

Schroth MN and Hancock JG (1982) Disease-suppressive soil and root-colonizing bacteria. Science 216:1376-81.

Silo-Suh LA, Lethbridge BJ, Raffel SJ, He H, Clardy J and Handelsman J (1994) Biological activities of two fungistatic antibiotics produced by Bacillus cereus UW85. Appl Environ Microbiol 60:2023-2030. 
Somers E, Vanderleyden J and Srinivasan M (2004) Rhizosphere bacterial signalling, a love parade beneath our feet. Crit Rev Microbiol 30:205-235.

Stephens PM, Crowley JJ and O'Connell C (1993) Selection of pseudomonad strains inhibiting Pythium ultimum on sugarbeet seeds in soil. Soil Biol Biochem 25:1283-1288.

Van Loon LC (2000) Systemic induced resistance. In: Slusarenko AJ, Fraser RSS and Van Loon LC (eds) Mechanisms of Resistance to Plant Diseases. Kluwer Academic Publishers, Dordrecht, pp 521-574.

Van Loon LC (2007) Plant responses to plant growth-promoting rhizobacteria. Eur J Plant Pathol 119:243-254.

Van Loon LC and Bakker PAHM (2006) Root-associated bacteria inducing systemic resistance. In: Gnanamanickam SS (ed.) Plant-Associated Bacteria. Springer, Dordrecht, pp 269316.

Van Loon LC, Bakker PAHM and Pieterse CMJ (1998) Systemic resistance induced by rhizosphere bacteria. Annu Rev Phytopathol 36:453-83.

Van Peer R and Schippers B (1992) Lipopolysaccharides of plant growth-promoting Pseudomonas sp. strain WCS417r induce resistance in carnation to fusarium wilt. Neth J Plant Pathol 98:129-39.

Van Peer R, Niemann GJ and Schippers B (1991) Induced resistance and phytoalexin accumulation in biological control of fusarium wilt of carnation by Pseudomonas sp. strain WCS417r. Phytopathology 91:728-34.

Van Wees SCM, Pieterse CMJ, Trijssenaar A, Van't Westend YAM, Hartog F and Van Loon LC (1997) Differential induction of systemic resistance in Arabidopsis by biocontrol bacteria. Mol Plant Microbe Interact 10:716-24.

Van Wees SCM, De Swart EAM, Van Pelt JA, Van Loon LC and Pieterse CMJ (2000) Enhancement of induced disease resistance by simultaneous activation of salicylate- and jasmonate-dependent defense pathways in Arabidopsis thaliana. Proc Natl Acad Sci USA 97:8711-6.
Van Wees SCM, Van der Ent S and Pieterse CMJ (2008) Plant immune responses triggered by beneficial microbes. Curr Opin Plant Biol 11:443-448.

Verhagen BWM, Van Loon LC and Pieterse CMJ (2006) Induced disease resistance signaling in plants. In: Silva JAT (ed) Floriculture, Ornamental and Plant Biotechnology Volume III. Global Science Books, Gainesville, pp 334-343.

Wandersman C and Delepelaire P (2004) Bacterial iron sources: From siderophores to hemophores. Annu Rev Microbiol 58:611-647.

Wei G, Kloepper JW and Tuzun S (1991) Induction of systemic resistance of cucumber to Colletotrichum orbiculare by select strains of plant growth-promoting rhizobacteria. Phytopathology 81:1508-1512.

Weller DM and Thomashow LS (1994) Current challenges in introducing beneficial microorganisms into the rhizosphere. In: O'Gara F, Dowling DN and Boesten B (eds) Molecular Ecology of Rhizosphere Microorganisms. Biotechnology and the Release of GMOs. VCH Verlagsgesellschaft, Weinheim, pp 1-18.

Whipps JM (2001) Microbial interactions and biocontrol in the rhizosphere. J Exp Bot 52:487-511.

Vleesschauwer D and Höfte M (2009) Rhizobacteria-induced systemic resistance. Adv Bot Res 51:223-281.

Zehnder G, Kloepper J, Yao C and Wei G (1997) Induction of systemic resistance in cucumber against cucumber beetles (Coleoptera, Chrysomelidae) by plant growth-promoting rhizobacteria. J Econ Entomol 90:391-396.

Zhang YL, Tessaro MJ, Lassner M and Li X (2003) Knockout analysis of Arabidopsis transcription factors TGA2, TGA5, and TGA6 reveals their redundant and essential roles in systemic acquired resistance. Plant Cell 15:2647-2653.

License information: This is an open-access article distributed under the terms of the Creative Commons Attribution License, which permits unrestricted use, distribution, and reproduction in any medium, provided the original work is properly cited. 